\title{
Carbon and nitrogen deposition on the surface of marginal sediments under different land use systems along the Paraopeba river basin (Minas Gerais, State)
}

The knowledge of the contents of organic compounds in aquatic ecosystems is of great importance, since the dissolved organic matter represents a dynamic component in the interaction between geospheres. The objective of this study was to evaluate the levels of carbon, nitrogen, and carbon-to-nitrogen ratio in the marginal sediments and the carbon content in the waters along the Paraopeba river basin (MG). The samples were collected in five locations (Jeceaba, Brumadinho, Fortuna de Minas, Florestal, and Três Marias) corresponding to the high, medium, and low river segments. The carbon content was determined by the Walkley \& Black method and the nitrogen content by the Kjeldahl method. The carbon content ranges from 4.75 to 5.97 $\mathrm{g} \mathrm{kg}^{-1}$. Nitrogen ranged from 0.73 to $1.08 \mathrm{~g} \mathrm{~kg}^{-1}$. Finally, the carbon-to-nitrogen ratio varied from 5.15 to 21.25 . The carbon content in the water samples ranged from 0 to $0.25 \mathrm{~g} \mathrm{~L}^{-1}$. As the values of dissolved organic carbon were very low or even zero, the nitrogen content and the carbon-to-nitrogen ratio were not determined. There was a negative and a positive correlation values of dissolved organic carbon were very low or even zero, the nitrogen content and the carbon-to-nitrogen ratio were not determined. There was a negative and a positive correlation
with the aluminum content $(r=-0.70$ and $r=0.74$, respectively) indicating possible contamination by heavy metals. Therefore, the levels of carbon, nitrogen, and the carbon-to-nitrogen ratio were sensitive indicators of changes in the aquatic ecosystem.

\section{Deposição de carbono e nitrogênio na superfície de sedimentos marginais sob diferentes sistemas de uso do solo ao longo da bacia do rio Paraopeba (Estado de Minas Gerais)}

O conhecimento dos teores de compostos orgânicos em ecossistemas aquáticos é de grande importância, uma vez que a matéria orgânica dissolvida representa um componente dinâmico na interação entre as geosferas. Objetivou-se nesse estudo avaliar os teores de carbono, nitrogênio e razão entre carbono e nitrogênio nas nos sedimentos marginais e o teor de carbono nas águas ao longo da bacia Rio Paraopeba-MG. As amostras foram coletas em cinco localidades (Jeceaba, Brumadinho, Fortuna de Minas, Florestal e Três Marias) correspondentes aos segmentos alto, médio e baixo curso do rio. Os teores de carbono foram determinados pelo método de Walkley \& Black e os de nitrogênio pelo método de Kjeldahl. Os teores de carbono variam de 4,75 a 5,97 g kg . O nitrogênio variou de 0,73 a 1,08 $\mathrm{g} \mathrm{kg}^{-1}$. E, por fim, a razão entre carbono e nitrogênio apresentou variação de 5,15 a 21,25. Os teores de carbono nas amostras de água oscilaram entre 0 a $0,25 \mathrm{~g} \mathrm{~L}^{-1}$. Como os valores de carbono orgânico dissolvido foram muito baixos ou mesmo zero não se determinaram os teores de nitrogênio e a razão entre carbono e nitrogênio. Verificou-se uma correlação negativa e uma positiva com o teor de alumínio ( $r=-0,70$ e $r=0,74$ respectivamente) indicando possível contaminação por metais pesados. Portanto, os teores de carbono, nitrogênio e razão entre carbono e nitrogênio, foram indicadores sensíveis de alterações ocorridas no ecossistema aquático.

Palavras-chave: Matéria orgânica; Sedimentação; Geoquímica; Manejo de solos.

\section{Topic: Ciências do Solo}

Reviewed anonymously in the process of blind peer
Received: 03/04/2021 Approved: 26/04/2021
Libério Junio da Silva (iD)

Instituto Brasileiro de Desenvolvimento e Sustentabilidade, Brasil http://lattes.cnpq.br/9162739267571634

http://orcid.org/0000-0002-6677-4645

liberiojunior25@gmail.com

Marihus Altoé Baldotto (it

Universidade Federal de Viçosa, Brasil

http://lattes.cnpq.br/3927892593585823

http://orcid.org/0000-0002-3239-9082

marihus@gmail.com

Lílian Estrela Borges Baldotto (D)

Universidade Federal de Viçosa, Brasil

http://lattes.cnpq.br/1050136826112749

http://orcid.org/0000-0003-1007-1489

lilian.estrela@ufv.br

\author{
Nilo Leal Sander \\ Instituto Brasileiro de Desenvolvimento e Sustentabilidade, Brasil \\ http://lattes.cnpq.br/6241511798904038 \\ http://orcid.org/0000-0001-9856-6819 \\ nilosander@gmail.com \\ Fernanda Figueiredo Granja Dorilêo Leite \\ Universidade Federal Fluminense, Brasil \\ http://lattes.cnpq.br/1286886361250323 \\ http://orcid.org/0000-0001-9004-6413 \\ fernandafgdleite@gmail.com
}

Referencing this:

SILVA, L. J.; BALDOTTO, M. A.; BALDOTTO, L. E. B.; SANDER, N. L.; LEITE, F. F. G. D.. Carbon and nitrogen deposition on the surface of marginal sediments under different land use systems along the Paraopeba river basin (Minas Gerais, State). Revista Ibero Americana de Ciências Ambientais, v.12, n.4, p.8-20, 2021. DOI:

http://doi.org/10.6008/CBPC2179-6858.2021.004.0002 


\section{INTRODUCTION}

Land use and land cover have a fundamental role in shaping the environment on a global, regional and local scale (FERREIRA et al., 2017; GUTIERREZ et al., 2017; CAMPELO et al., 2020). Changes in land use and land cover influence the biological diversity (OLSON, 1985), climate (PANHOTA et al., 2003), biogeochemical and water cycles (MEIXNER et al., 1999). The removal of native forest results on the increases of soil temperature, erosion, changes in water balance and nutrient availability (VITOUSEK et al., 1979; SWANK et al., 1988). Consequently, the transport of sediments, organic materials, and nutrients of associated rivers are also altered, generally, in a vicious cycle of environmental disturbances (PANHOTA et al., 2003).

The degradation of organic matter in aquatic ecosystems gives rise to a complex cycle of $\mathrm{C}$ (carbon) and $\mathrm{N}$ (nitrogen) that determines both the structures and the functioning of aquatic ecosystems (SILVA, 2019; CUNHA, 2020). According to Mayers et al. (1999), organic matter goes into these systems in the form of dissolved (DOC) and particulate organic carbon (POC) and originates from the complex mixture of lipids, carbohydrates, proteins, and other compounds produced by organisms that live in the lakes and in its drainage basin. For Wetzel et al. (1995), the biochemical transformation of organic matter introduced by microbial metabolism is fundamental to the dynamics of nutrient cycles and to the energy flow of aquatic ecosystems. Thus, the incorporation of organic material in the marginal sediments along the course of the rivers may have an allochthonous or autochthonous origin (WETZEL, 1992).

Similar to $\mathrm{C}, \mathrm{N}$ is also found in its dissolved and particulate forms in aquatic ecosystems, having native and alien origin (CÓNSUL, 2004). For example, in agricultural areas, the runoff of rainwater through fertilized soils is also responsible for the incorporation of $\mathrm{N}$ into the sediments of the rivers, as well as in urban areas, where the rainwater drainage associated with the deficient public sanitation system are a potent source of nitrogenous components for rivers (MOROZOVA et al., 2003).

Within this context, there is the Paraopeba River, which is located in the southeast of the state of Minas Gerais, corresponding to an area of $12,054 \mathrm{~km}^{2}$, covering 48 municipalities, inserted in a transition area between the Atlantic Forest and Cerrado biomes. It is one of the main tributaries of the São Francisco River. In addition, it exhibits very diverse landscapes, cultures, and socioeconomic and environmental realities, being of great importance for the state, mainly for the metropolitan region of Belo Horizonte, which has $53 \%$ of its population supplied by the waters of the river.

It is worth mentioning that on the last 25th of January 2019, the rupture of the "Córrego do Feijão" dam in the municipality of Brumadinho strongly affected the Paraopeba River. It prevented the water distribution in several municipalities through which the river flows, since 12 million cubic meters were spread along the river, leaving more than 250 people dead (THOMPSON et al., 2020). Furthermore, there was a metal level increase of 21 times the acceptable level (RODRIGUES FILHO et al., 2019), destroying 113.27 ha of the Atlantic Forest and 70.65 ha of protected areas along the river's course.

Given this premise, the objective of the present study was to analyze the levels of $\mathrm{C}$, total $\mathrm{N}$, and $\mathrm{C} / \mathrm{N}$ ratio in marginal sediment samples and $\mathrm{C}$ in water samples over five municipalities corresponding to the high, 
medium, and low course of the river, before the dam burst. We also correlated these attributes with the chemical and physical attributes of the soils surrounding the Paraopeba River.

\section{MATERIALS AND METHODS}

\section{Study area}

We carried out the research in five municipalities along the Paraopeba-MG River basin, in regions corresponding to the segments known as high, medium, and low course of the river. The municipalities (and in parentheses the geographic coordinates) are Jeceaba ( $20^{\circ} 32$ ' 6 "S and $43^{\circ} 58^{\prime} 58^{\prime \prime} \mathrm{O}$ ), corresponding to the upper Paraopeba, with a temperate climate and mild summer, with temperatures oscillating around 18응 at 22두 Brumadinho (20 08 '34 "S and 44 12' 00" O) and Florestal (19o 53 '20"S and 44 25' 58 "O), which belong to the medium Paraopeba, with a temperate climate and hot summer, with temperatures around 19응 to 24ㄷ; and finally Três Marias (18ㅇ $12^{\prime 2} 21^{\prime \prime} \mathrm{S}$ and 45o 14 '31" O); and Fortuna de Minas (19o 33 '39 "S and $44{ }^{\circ} 26^{\prime} 49^{\prime \prime}$ O), which, in turn, are located in the lower Paraopeba, with a rainy, hot and humid tropical climate, with dry winter and rainy summer (Figure 1).

\section{Sampling}

Sampling was carried out on the margins of the basin, as shown in the Figure below with the respective points of geographic location (Figure 1). The sediment samples were collected only in the superficial layer $(2 \mathrm{~cm}$ deep) corresponding to the active layer of the sediment, with the assistance of a spatula. We collected the water samples with the aid of a polypropylene bottle. All samples were hermetically sealed and placed in a temperature-controlled cool box until they arrived at the laboratory, where we froze the samples for further analysis.

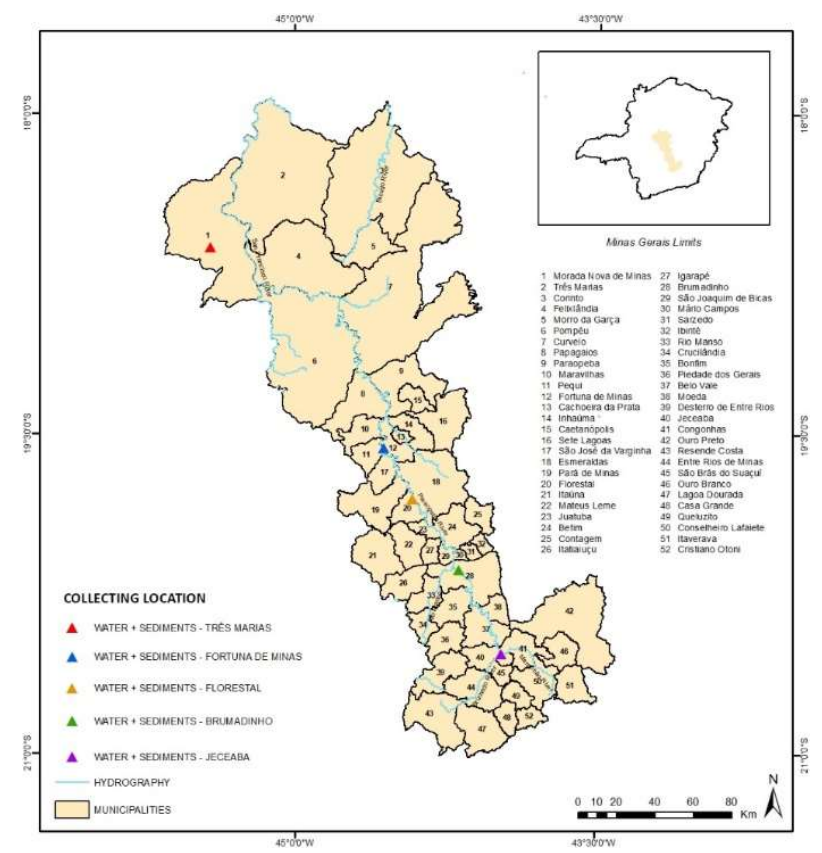

Figure 1: Geographic location of the water and sediment collection points on the banks of the Paraopeba River Basin (MG). 
The soil samples were only sampled in the superficial layer $(0-20 \mathrm{~cm}$ deep) according to EMBRAPA (1997), taken from different points, considering three systems of soil use and management: Native forest, pasture, and shrubbery (areas in process of regeneration with small agglomerated vegetation). We collected the soil in two samples, which were packed in plastic bags, taken to the laboratory, removed, sieved in a 2 $\mathrm{mm}$ mesh, and air-dried.

\section{Chemical analysis}

\section{Organic Carbon in Water and Sediments}

The determination of the $\mathrm{C}$ content in marginal sediments and water was carried out using the wet method according to Walkley \& Black (1934), according to EMBRAPA (1997; 2013). It consists of the sulfur oxidation of organic material. For the analysis of the carbon content in water, we used an aliquot of $2 \mathrm{~mL}$ of water, which was mixed with $10 \mathrm{~mL}$ of $\mathrm{K}_{2} \mathrm{Cr}_{2} \mathrm{O}_{7}$ solution and $25 \mathrm{~mL}$ of $\mathrm{H}_{2} \mathrm{SO}_{4}$ p.a. in $125 \mathrm{~mL}$ conical flasks, at room temperature $\left( \pm 25^{\circ} \mathrm{C}\right)$. After cooling, we added $40 \mathrm{~mL}$ of distilled water, $10 \mathrm{~mL}$ of $\mathrm{H}_{3} \mathrm{PO}_{4}$ p.a. and titration with $\left(\mathrm{NH}_{4}\right) 2 \mathrm{Fe}\left(\mathrm{SO}_{4}\right)_{2} \cdot 6 \mathrm{H}_{2} \mathrm{O}$ solution, using the $1 \%$ diphenylamine acid solution as an indicator. The procedure was performed in duplicate and, in parallel, blank tests were performed.

\section{Nitrogen in Sediments}

The $\mathrm{N}$ content in the sediments was determined by the method of Kjeldahl (1883), as proposed by EMBRAPA (1997), where the $\mathrm{N}$ present in approximately $0.5 \mathrm{~g}$ of sediment is converted into ammonium sulfate through oxidation, with a digesting mixture based on $\mathrm{CuSO}_{4}, \mathrm{NaSO}_{4}$, and selenium. We carried out the digestion in a hot plate or digesting block under a temperature above $360{ }^{\circ} \mathrm{C}$, for approximately five hours, with subsequent steam distillation. The distillate was collected in an $\mathrm{H}_{3} \mathrm{BO}_{3}$ solution $\left(20 \mathrm{~g} \mathrm{~L}^{-1}\right)$, mixed with a solution of bromocresol green and methyl red, and then titrated with a solution of $\mathrm{HCL} 0.05 \mathrm{~mol} \mathrm{~L}^{-1}$, until the boric acid indicator solution turns orange. The nitrogen content was verified in duplicate, with blank tests.

\section{Fertility of surrounding soils}

For the chemical characterization of soils and to assist in the discussion of results, the $\mathrm{pH}$ in the water and the levels of $\mathrm{P}$ and $\mathrm{K}$ available by the Mehlich ${ }^{-1}$ extractor $\left(\mathrm{mg} \mathrm{dm}^{-3}\right) \cdot \mathrm{Ca}^{2+}, \mathrm{Mg}^{2+}$, exchangeable acidity, and potential acidity were determined $\left(\mathrm{cmolc} \mathrm{dm}^{-3}\right)$ in the basement soils, in the five sampling municipalities, considering only the active soil layer (20 cm deep). Based on the results, the values of the sum of bases (V\%) and saturation by aluminum ( $\mathrm{m} \%$ ) were calculated. We based all the chemical determinations on standard EMBRAPA techniques (1997).

\section{Statistical Analysis}

In order to compare the soil fertility in the five sampled municipalities and the incorporation of $\mathrm{C}$ and $\mathrm{N}$ in the sediments from the Paraopeba river basin, the mean and standard error for each experimental 
Carbon and nitrogen deposition on the surface of marginal sediments under different land use systems along the Paraopeba river basin (Minas

variable was estimated (one-way ANOVA, $P<0,0001$ ). We also performed a multivariate analysis of the data, obtaining the cluster test, using the Euclidean distance - a measure of dissimilarity between the samples, determined from the variables of a sample set. The result of the multivariate analysis of the data was a dendrogram, in which the more distant the samples, the smaller their similarity (CRUZ, 2006). We also performed the Pearson's correlation analysis between the chemical attributes of the soil and the chemical attributes of water and sediments (STEEL et al., 1960). All analyzes were performed using the R Core Team program.

\section{RESULTS AND DISCUSSION}

\section{Soil fertility}

The results were interpreted from the recommendations for the state of Minas Gerais, presented by Alvarez et al. (1999) and shown by Baldotto et al. (2015). They are exposed in the table below (Table 1). The $\mathrm{pH}$ values were average in the Forest and Shrubbery systems in Fortuna de Minas, and the active acidity was high $(\mathrm{pH} \geq 4.0)$ in the Shrubbery and Pasture systems in the municipalities of Jeceaba, Brumadinho, Florestal, and Três Marias, respectively.

The organic matter content for the superficial layers of marginal sediments $(0-20 \mathrm{~cm})$ presented average levels in all sampled municipalities and all systems of use and management of the soils surrounding the basin. The exception was in the Shrubbery system, which presented low levels of organic matter, what can be linked to low waste inputs, since these areas are systems in a process of regeneration (AYRES NETO et al., 2016).

The soil under the Forest system showed high $\mathrm{pH}$ in the municipalities of Jeceaba and Brumadinho. The results of chemical analyzes in the superficial layer $(0-10 \mathrm{~cm})$ of the soils surrounding the Paraopeba River basin are shown in Table 1. Regarding the exchangeable acidity, it was moderate in the Shrubbery, Pasture and Forest systems for all municipalities along the Paraopeba River, with $\mathrm{Al}^{3+}$ being equal to zero in all systems in the municipality of Jeceaba, moderate in the Forest, Shrubbery and Pasture in the municipalities of Brumadinho, Florestal and Fortuna de Minas, and high in the Forest system in Três Marias.

Considering the phosphorus content, we observed very low magnitudes in all systems in every municipality, except for the Forest in Fortuna de Minas system (33.5 mg dm $\mathrm{dm}^{-3}, \mathrm{CV}=23 \%$ ). In all evaluated systems, the levels of $\mathrm{Ca}^{2+}$ and $\mathrm{Mg}^{2+}$ varied from very low to medium. Regarding the $\mathrm{K}$ content, it was classified as good for all systems except the Forest and Pasture system in Brumadinho, the Shrubbery system in Florestal and all systems in Fortuna de Minas, which were very low, and the Forest and Pasture systems in Três Marias. However, the values that we obtained were not sufficient to alter the result of the sum of bases that remained between the very low to average classes, except for the Pasture system in Fortuna de Minas and Três Marias.

The cation exchange capacity (CEC), both effective $(t)$ and total $(T)$, varied from low to medium, for all systems in all sampling municipalities. When relating the sum of bases (SB) to the CTC of the soils, we 
Carbon and nitrogen deposition on the surface of marginal sediments under different land use systems along the Paraopeba river basin (Minas Gerais, State)

SILVA, L. J.; BALDOTTO, M. A.; BALDOTTO, L. E. B.; SANDER, N. L.; LEITE, F. F. G. D.

noted that the base saturation (V) in all systems varied from low to very low, indicating low soil fertility along the Paraopeba River.

Table 1: Chemical analysis of soils in the five sampling regions along the Paraopeba River.

\begin{tabular}{|c|c|c|c|c|c|c|c|c|c|c|c|c|c|c|c|}
\hline County & Sample & & SOM & $\mathrm{pH}$ & $\mathbf{P}$ & K & $\mathrm{Ca}^{2+}$ & $\mathbf{M g}^{2+}$ & $\mathrm{Al}^{3+}$ & $\mathrm{H}+\mathrm{Al}$ & SB & t & $\mathbf{T}$ & $\mathbf{v}$ & m \\
\hline & \multicolumn{2}{|c|}{ Management } & dag $\mathrm{kg}^{-1}$ & & \multicolumn{2}{|c|}{--mg dm-3-- } & \multicolumn{6}{|c|}{ 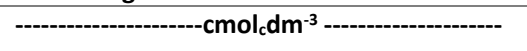 } & & \multicolumn{2}{|c|}{--------\%----- } \\
\hline \multirow[t]{9}{*}{ Jeceaba } & \multirow[t]{3}{*}{ Forest } & Mean & 5,5 & 6,5 & 3,2 & 65,9 & 3,4 & 3,0 & 0,0 & 2,4 & 6,6 & 6,6 & 8,9 & 73,5 & 0,0 \\
\hline & & SD & 0,3 & 0,7 & 0,1 & 5,5 & 0,0 & 0,0 & 0,0 & 0,2 & 0,1 & 0,1 & 0,2 & 1,7 & 0,0 \\
\hline & & $\begin{array}{l}\mathrm{CV} \\
\text { (\%) }\end{array}$ & 4,6 & 10,1 & 2,1 & 8,4 & 0,7 & 1,5 & 0,0 & 7,8 & 0,9 & 0,9 & 1,7 & 2,3 & 0,0 \\
\hline & \multirow[t]{3}{*}{ Shrubbery } & Mean & 5,8 & 4,7 & 2,5 & 78,7 & 2,5 & 1,8 & 0,0 & 1,5 & 4,5 & 4,5 & 5,9 & 75,4 & 0,0 \\
\hline & & SD & 0,5 & 0,5 & 0,1 & 0,0 & 0,0 & 0,1 & 0,0 & 0,1 & 0,1 & 0,1 & 0,1 & 1,5 & 0,0 \\
\hline & & $\begin{array}{l}\mathrm{CV} \\
\text { (\%) }\end{array}$ & 8,0 & 11,0 & 4,7 & 0,0 & 0,9 & 5,0 & 0,0 & 6,4 & 2,5 & 2,5 & 1,8 & 2,0 & 0,0 \\
\hline & \multirow{3}{*}{ Pasture } & Mean & 5,4 & 4,1 & 1,7 & 177,5 & 2,3 & 2,5 & 0,1 & 3,7 & 5,2 & 5,3 & 8,9 & 58,9 & 1,8 \\
\hline & & SD & 0,0 & 0,1 & 0,2 & 27,6 & 0,0 & 0,0 & 0,0 & 0,1 & 0,1 & 0,1 & 0,0 & 1,0 & 0,0 \\
\hline & & $\begin{array}{l}\text { CV } \\
\text { (\%) }\end{array}$ & 0,7 & 1,6 & 9,0 & 15,6 & 2,0 & 1,6 & 0,0 & 2,5 & 1,6 & 1,6 & 0,3 & 1,7 & 1,6 \\
\hline \multirow[t]{9}{*}{ Brumadinho } & \multirow[t]{3}{*}{ Forest } & Mean & 3,1 & 6,6 & 1,5 & 37,3 & 0,9 & 1,0 & 1,0 & 6,9 & 1,9 & 2,9 & 4,9 & 39,8 & 33,9 \\
\hline & & SD & 0,1 & 0,6 & 0,2 & 5,5 & 0,0 & 0,1 & 0,0 & 0,1 & 0,1 & 0,1 & 0,1 & 0,2 & 0,6 \\
\hline & & $\begin{array}{l}\mathrm{CV} \\
\text { (\%) }\end{array}$ & 4,0 & 9,4 & 13,3 & 14,8 & 2,6 & 6,2 & 0,0 & 1,2 & 2,7 & 1,8 & 2,1 & 0,6 & 1,8 \\
\hline & \multirow[t]{3}{*}{ Shrubbery } & Mean & 1,7 & 4,9 & 3,3 & 78,7 & 1,7 & 1,6 & 0,9 & 7,5 & 3,5 & 4,3 & 7,8 & 44,4 & 20,2 \\
\hline & & SD & 0,1 & 0,5 & 0,6 & 0,0 & 0,2 & 0,2 & 0,1 & 0,1 & 0,0 & 0,1 & 0,1 & 0,3 & 1,0 \\
\hline & & $\begin{array}{l}\mathrm{CV} \\
\text { (\%) }\end{array}$ & 6,0 & 10,1 & 18,3 & 0,0 & 10,4 & 11,2 & 6,0 & 1,1 & 1,1 & 1,5 & 1,2 & 0,7 & 4,9 \\
\hline & \multirow[t]{3}{*}{ Pasture } & Mean & 3,9 & 4,2 & 2,0 & 40,4 & 1,5 & 0,2 & 0,7 & 4,2 & 1,8 & 2,5 & 4,3 & 41,9 & 27,8 \\
\hline & & SD & 0,2 & 0,2 & 0,9 & 0,0 & 0,1 & 0,1 & 0,1 & 0,1 & 0,0 & 0,2 & 0,2 & 1,3 & 4,0 \\
\hline & & $\begin{array}{l}\text { CV } \\
\text { (\%) }\end{array}$ & 4,8 & 3,6 & 43,2 & 0,0 & 6,7 & 40,8 & 19,9 & 3,6 & 2,2 & 6,3 & 4,2 & 3,2 & 14,3 \\
\hline \multirow[t]{9}{*}{ Florestal } & \multirow[t]{3}{*}{ Forest } & Mean & 4,5 & 4,4 & 2,6 & 78,7 & 1,8 & 0,7 & 0,4 & 6,6 & 2,7 & 3,1 & 5,8 & 46,4 & 13,5 \\
\hline & & SD & 0,1 & 0,1 & 0,3 & 0,0 & 0,1 & 0,1 & 0,2 & 0,0 & 0,1 & 0,2 & 0,3 & 1,2 & 4,0 \\
\hline & & $\begin{array}{l}\mathrm{CV} \\
(\%)\end{array}$ & 2,4 & 3,1 & 13,3 & 0,0 & 3,8 & 15,2 & 35,3 & 0,0 & 2,9 & 6,1 & 4,3 & 2,5 & 29,8 \\
\hline & \multirow[t]{3}{*}{ Shrubbery } & Mean & 4,3 & 4,3 & 7,8 & 59,6 & 1,9 & 1,0 & 0,2 & 5,8 & 3,0 & 3,2 & 6,3 & 48,4 & 6,1 \\
\hline & & SD & 0,0 & 0,1 & 0,6 & 0,0 & 0,0 & 0,1 & 0,0 & 0,2 & 0,1 & 0,1 & 0,2 & 0,0 & 0,1 \\
\hline & & $\begin{array}{l}\mathrm{CV} \\
(\%)\end{array}$ & 0,1 & 1,5 & 8,2 & 0,0 & 2,1 & 6,6 & 0,0 & 4,2 & 2,6 & 2,4 & 2,5 & 0,1 & 2,4 \\
\hline & \multirow[t]{3}{*}{ Pasture } & Mean & 4,0 & 4,0 & 3,3 & 72,3 & 0,8 & 0,1 & 1,0 & 6,3 & 1,1 & 2,1 & 3,2 & 34,2 & 47,9 \\
\hline & & SD & 0,1 & 0,1 & 0,8 & 5,5 & 0,0 & 0,1 & 0,1 & 0,2 & 0,1 & 0,0 & 0,1 & 1,1 & 2,6 \\
\hline & & $\begin{array}{l}\mathrm{CV} \\
\text { (\%) }\end{array}$ & 1,9 & 2,1 & 22,8 & 7,6 & 2,9 & 55,8 & 5,6 & 2,9 & 4,9 & 0,1 & 1,6 & 3,3 & 5,5 \\
\hline \multirow{9}{*}{$\begin{array}{l}\text { Fortuna de } \\
\text { Minas }\end{array}$} & \multirow[t]{3}{*}{ Forest } & Mean & 5,5 & 5,4 & 33,5 & 31,7 & 5,0 & 2,3 & 0,1 & 2,2 & 7,3 & 7,4 & 14,8 & 49,7 & 1,3 \\
\hline & & SD & 0,3 & 0,0 & 8,0 & 12,8 & 0,5 & 0,1 & 0,0 & 0,1 & 0,6 & 0,6 & 1,1 & 0,0 & 0,1 \\
\hline & & $\begin{array}{l}\text { CV } \\
\text { (\%) }\end{array}$ & 5,3 & 0,6 & 23,9 & 40,5 & 10,4 & 3,0 & 0,0 & 4,2 & 7,7 & 7,6 & 7,6 & 0,0 & 7,3 \\
\hline & \multirow[t]{3}{*}{ Shrubbery } & Mean & 6,0 & 5,5 & 1,8 & 8,0 & 0,2 & 0,6 & 0,0 & 3,2 & 0,9 & 0,9 & 1,8 & 50,0 & 0,0 \\
\hline & & SD & 0,4 & 0,3 & 0,3 & 0,6 & 0,2 & 0,2 & 0,0 & 0,1 & 0,3 & 0,3 & 0,5 & 0,0 & 0,0 \\
\hline & & $\begin{array}{l}\text { CV } \\
\text { (\%) }\end{array}$ & 6,4 & 4,6 & 16,1 & 7,3 & 68,1 & 27,6 & 0,0 & 2,9 & 29,3 & 29,3 & 29,3 & 0,0 & 0,0 \\
\hline & Pasture & Mean & 5,4 & 6,0 & 1,7 & 20,8 & 0,3 & 0,3 & 0,2 & 1,4 & 0,6 & 0,9 & 1,5 & 41,4 & 27,7 \\
\hline & & SD & 0,1 & 0,4 & 0,2 & 0,0 & 0,2 & 0,3 & 0,2 & 0,0 & 0,4 & 0,4 & 0,9 & 7,1 & 20,5 \\
\hline & & $\begin{array}{l}\text { CV } \\
(\%)\end{array}$ & 1,1 & 6,4 & 8,9 & 0,0 & 54,6 & 102,6 & 99,0 & 0,0 & 69,4 & 51,2 & 57,0 & 17,2 & 74,2 \\
\hline Três Marias & Forest & Mean & 4,4 & 4,4 & 2,0 & 50,0 & 0,5 & 0,5 & 1,2 & 5,8 & 1,1 & 2,3 & 3,4 & 32,7 & 51,2 \\
\hline & & SD & 0,2 & 0,1 & 0,1 & 4,0 & 0,0 & 0,2 & 0,2 & 0,2 & 0,3 & 0,3 & 0,5 & 3,6 & 7,7 \\
\hline & & $\begin{array}{l}\mathrm{CV} \\
\text { (\%) }\end{array}$ & 5,2 & 3,0 & 3,5 & 7,9 & 8,4 & 48,3 & 14,4 & 4,2 & 22,6 & 12,2 & 14,8 & 10,9 & 15,0 \\
\hline & Pasture & Mean & 4,4 & 4,3 & 1,3 & 35,6 & 1,2 & 0,5 & 1,0 & 4,5 & 1,9 & 2,9 & 4,8 & 39,0 & 35,9 \\
\hline & & SD & 0,1 & 0,1 & 0,0 & 3,6 & 0,0 & 0,2 & 0,1 & 0,5 & 0,2 & 0,2 & 0,4 & 1,4 & 3,8 \\
\hline & & $\begin{array}{l}\mathrm{CV} \\
\text { (\%) }\end{array}$ & 3,0 & 3,3 & 2,7 & 10,0 & 1,8 & 42,2 & 5,4 & 11,6 & 12,2 & 6,9 & 8,9 & 3,6 & 10,5 \\
\hline
\end{tabular}

* SD= Standard deviation; $\mathrm{CV}=$ Coefficient of variation

\section{Organic Carbon, Total Nitrogen and C/N Ratio in Sediments}

The results of $\mathrm{C}$ levels in the five sampled municipalities are shown in Figure 2. It is possible to see 
that the $\mathrm{C}$ levels ranged from $4.75 \mathrm{~g} \mathrm{~kg}^{-1}$ to $5.97 \mathrm{~g} \mathrm{~kg}^{-1}$, and did not show any statistical difference considering the margin of error $(p<0.0001)$.

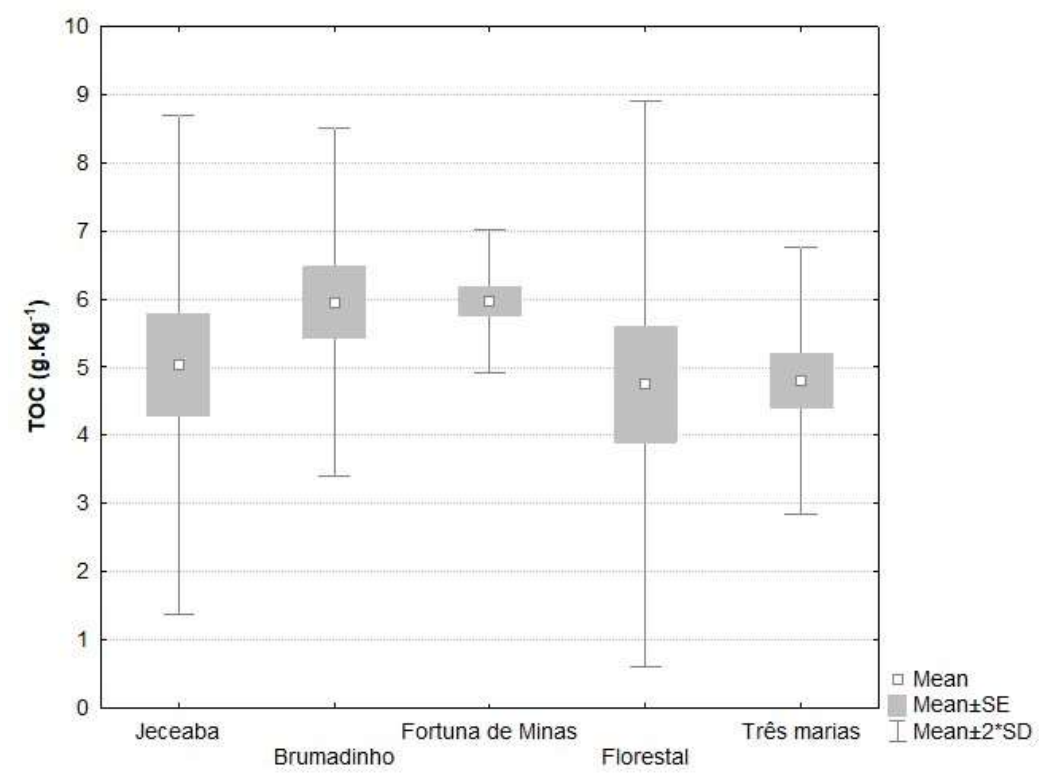

Figure 2: C levels in sediments from different regions sampled around the Paraopeba River basin (MG).

The high levels of organic $C$ verified in the sediments of this study were higher than those found by Ayres Neto et al. (2016), when studying the origin of the deposition of organic matter in mangrove sediments in the northwestern portion of the "Todos os Santos" Bay, where the maximum value found is around $3.99 \mathrm{~g}$ $\mathrm{kg}^{-1}$ in eight immersed stations. The higher $\mathrm{C}$ values in the sediments in the present work are indicative that the regions may be subject to large contributions of organic waste (anthropic or not). They may come from the tributaries of the Paraopeba River basin or even happen by the contribution of organic material coming from the surrounding areas of the river, since it is located close to urban and rural areas with intense agricultural and extractive production (e.g., sand extraction and mining activity).

Another fact that can also explain the incorporation of $\mathrm{C}$ in marginal sediments is the decomposition of heterotrophic planktonic organisms, such as bacteria and protozoa (WETZEL, 1992; LIMA, 2007; TUMIATI et al., 2020). It should be noted that sediments, due to their more oxide mineralogy (positive charges) and more soluble OM, are negatively charged. Sediments from tropical regions tend to sequester more carbon (CARDOSO et al., 2014; KALAIVANAN et al., 2017)

The $C$ content of the sediments $\left(C_{\text {sed }}\right)$ correlated negatively with the $\left.A\right)^{3+}$ content $(r=-0.70)$ (Figure. $3 \mathrm{~A})$, and this fact can be attributed to the $\mathrm{pH}$, since low $\mathrm{pH}$ values increase the levels of $\mathrm{Al}^{3+}$ and soil acidity. Thus, it appears that an increase in the content of OM provided an increase in the levels of $C$, leading to a reduction in the content of $\mathrm{Al}^{3+}$ and concomitantly reducing its saturation and potential acidity (OLIVEIRA, 2018). 

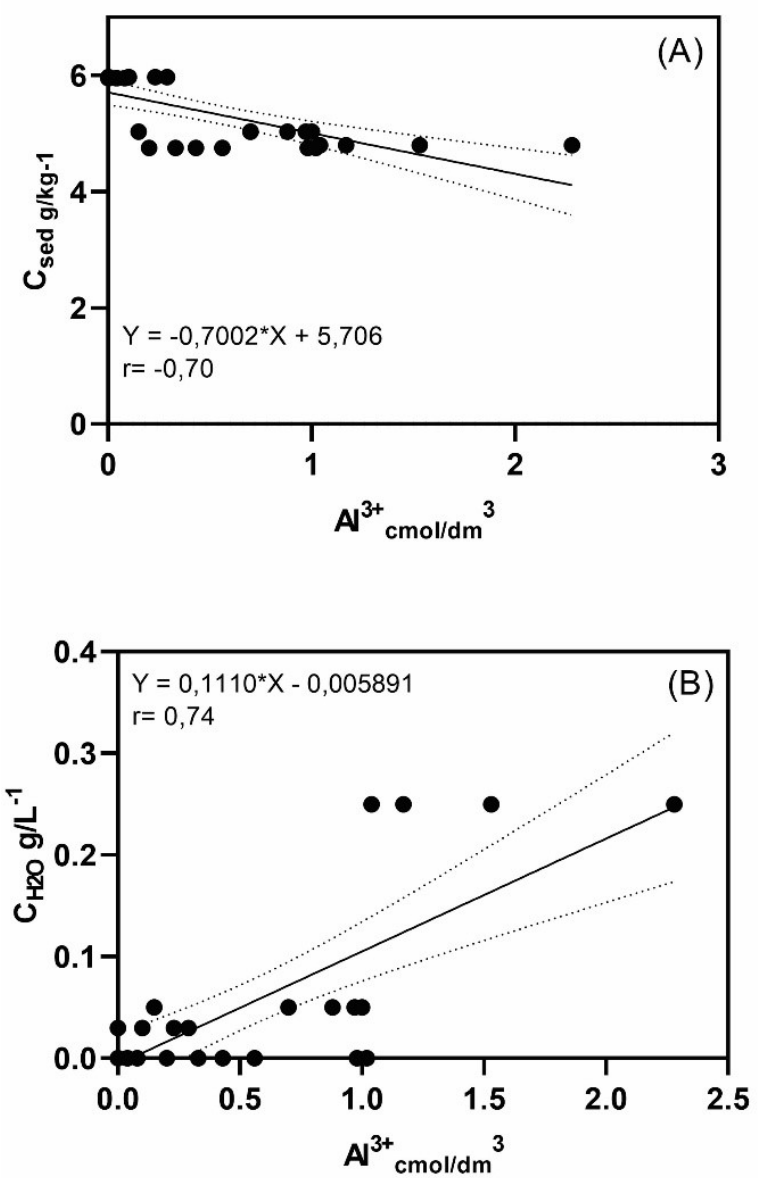

Figure 3: Correlation between the aluminum content $\left(\mathrm{Al}^{3+}\right)$ versus the total carbon content in the sediments $\left(\mathrm{C}_{\text {sed }}\right)(\mathrm{A})$ and carbon present in the waters $\left(\mathrm{C}_{\mathrm{H} 2 \mathrm{O}}\right)(\mathrm{B})$.

For $\mathrm{N}$ (Figure 4), the levels ranged from $0.28 \mathrm{~g} \mathrm{~kg}^{-1}$ to $1.08 \mathrm{~g} \mathrm{~kg}^{-1}$. The Florestal region presented the highest value $\left(1.08 \mathrm{~g} \mathrm{~kg}^{-1}\right)$, which was $28 \%$ higher than the others municipalities, followed by the Fortuna de Minas $\left(0.94 \mathrm{~g} \mathrm{~kg}^{-1}\right)$ and Brumadinho $\left(0.76 \mathrm{~g} \mathrm{~kg}^{-1}\right)$, showing an increasing trend in the average portion of the Paraopeba River towards its mouth in the Três Marias region. The lowest $\mathrm{N}$ content was observed in the Jeceaba region $\left(0.28 \mathrm{~g} \mathrm{~kg}^{-1}\right)$. It is worth mentioning that the lower $\mathrm{C}$ and $\mathrm{N}$ values found in the municipality of Jeceaba may be a consequence of the fact that it is located in a poorly preserved headboard, found during the sampling.

Our results for $\mathrm{N}$ were superior to those found by Pereira et al. (2006). When verifying the chemical characterization and relevant geochemical aspects of the suspended sediment matter at the mouth of the Amazon River, they found very low concentrations of $\mathrm{N}$, with maximum values reaching the level of $0.13 \mathrm{~g}$ $\mathrm{kg}^{-1}$. The higher concentrations of $\mathrm{N}$ can be associated with domestic sewage inputs and incorporation of nitrogen fertilizers, since the middle portion of the river is inserted in an area of intense agricultural production, which incorporates the organomineral particles present in the sediments, as Cebron et al. (2005) proposed.

As for the $\mathrm{C} / \mathrm{N}$ ratio (Figure 5 ), it is possible to notice that the region that presented the highest value was Brumadinho, which presented a $47 \%$ higher $\mathrm{C} / \mathrm{N}$ ratio compared to the other regions under study $(\mathrm{p}$ $<0.001)$. 


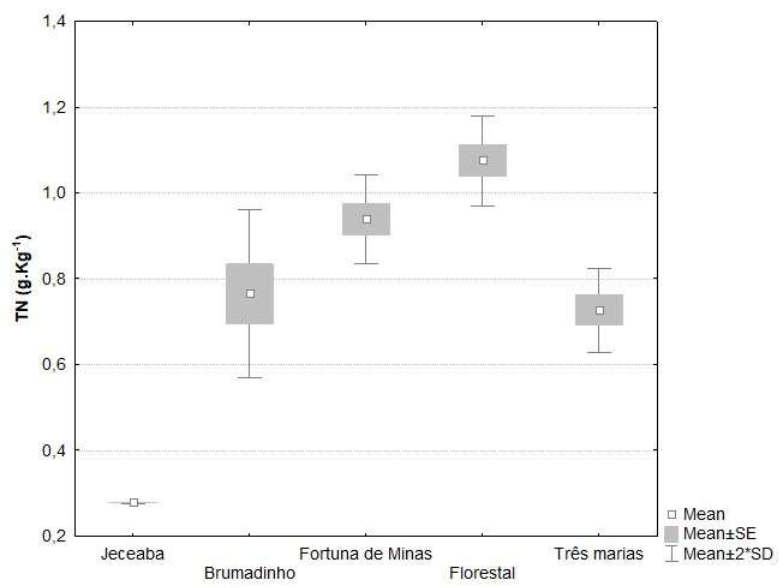

Figure 4: $\mathrm{N}$ content in sediments from different regions sampled around the Paraopeba River basin (MG).

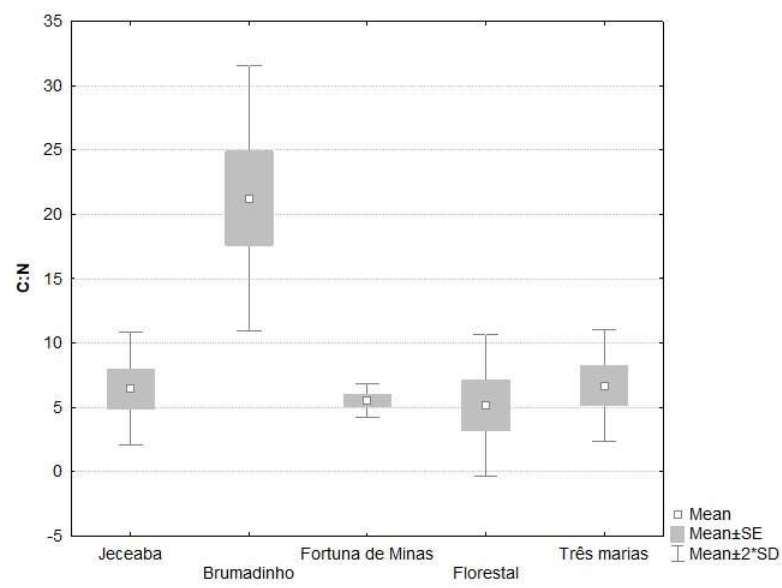

Figure 5: $\mathrm{C} / \mathrm{N}$ ratio in sediments from different regions sampled around the Paraopeba River basin (MG).

Regarding the stability of OM ( $\mathrm{C} / \mathrm{N}$ ratio), the values were higher than those found by Almeida et al. (2007), which worked on temporal variation, transport and partition of mercury and organic carbon in the particulate and dissolved fractions of the water column of the lower basin of the Paraíba do Sul River, RJ, where the smallest and largest values oscillated around 4 to 10. The median region of the Paraopeba River suffers from periodic fires by the producers to clean the pastures. The residues of the carbonized organic matter (e.g., lignin and cellulose) can increase the $\mathrm{C} / \mathrm{N}$ ratio by up to 80 (DICK et al., 2013), due to the contribution of aromatic groups $(C=C)$, which contribute to the increase in the aromaticity of organic matter.

Therefore, the variation of the values obtained by the $\mathrm{C} / \mathrm{N}$ ratios, as observed in this study may be related to the organic matter pyrogenesis, to granulometric differences between one point and another, and to the selective degradation of the OM components. Moreover, it can also be related to the lower rate of preservation of $\mathrm{N}$ concerning $\mathrm{C}$, with the use of cultural and persistent fire, which is often used in the region, increasing the $\mathrm{C} / \mathrm{N}$ ratio (BADER, 1955).

The regions that obtained the lowest values of $\mathrm{C}, \mathrm{N}$, and $\mathrm{C} / \mathrm{N}$ ratio can be explained by the lower entrance of $\mathrm{OM}$ of allochthonous and autochthonous origin in the system, by its oxidation, and by the incorporation of less lignified products in the sediments, which facilitates rapid decomposition by microorganisms (CANUEL, 2001). Those parameters are also influenced by the flow of the river and the season, increasing in rainy periods, a fact that occurred during the collections, which we carried out during periods of high rainfall.

To better explain the data in terms of grouping, we performed a multivariate analysis on the entire data set, generating four dendrograms represented by Figures $6 a, 6 b, 6 c$, and $6 d$, which indicated the division between groups of samples, with higher and smaller Euclidean distance, that is, less or more similar (CRUZ, 2006), in both sampling regions.

In this analysis, for the carbon of the marginal sediment samples, we grouped the municipalities of Jeceaba, Três Marias, and Florestal separately from the municipalities of Brumadinho and Fortuna de Minas (Figure 6a). Still, in the dendrogram, it is possible to observe that Jeceaba stands out in its group, being different. Regarding N (Figure 6b), we obtained two groups: one formed by the municipalities of Brumadinho 
and Três Marias; and the other formed by Fortuna de Minas and Florestal, indicating similarity in the levels of $\mathrm{N}$. The municipality of Jeceaba, on the other hand, grouped separately from the others, being different. In the dendrogram obtained for the $\mathrm{C} / \mathrm{N}$ ratio (Figure $6 \mathrm{c}$ ), we observed the formation of two groups: one formed by the municipalities of Florestal and Fortuna de Minas and the other formed by Jeceaba and Três Marias, showing similarities between the $\mathrm{C} / \mathrm{N}$ ratio. The municipality of Brumadinho is grouped separately being the most dissimilar. Finally, for the carbon verified in the waters (Figure 6d), we grouped the municipalities of Brumadinho, Fortuna de Minas, and Florestal separately from the municipalities of Jeceaba and Três Marias, which were the most different.
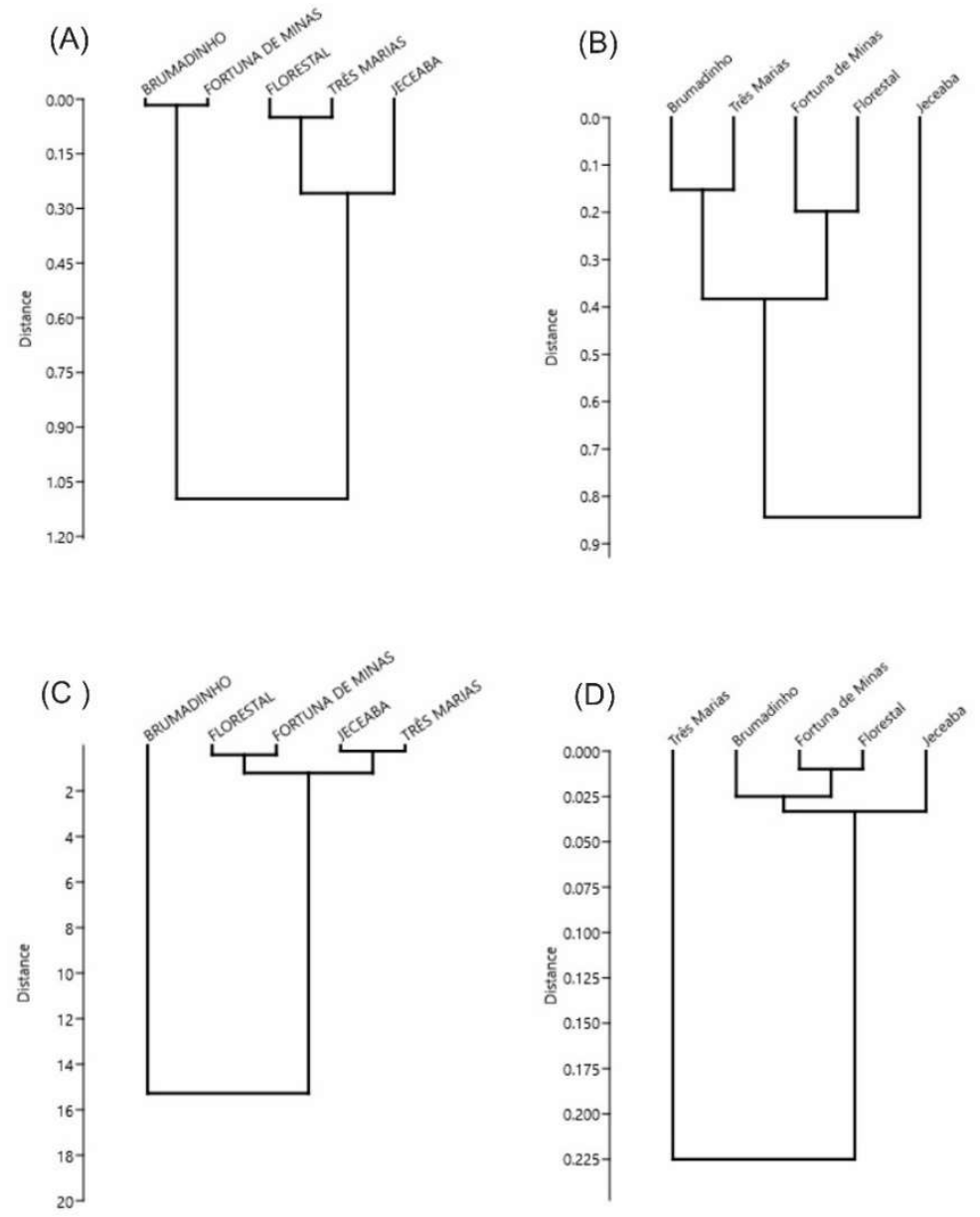

Figure 6: Grouping by minimum variance and Euclidean distance using multivariate analysis for the data set of the studied samples.

\section{Total Organic Carbon in Water Samples $\left(\mathrm{C}_{\mathrm{H} 2 \mathrm{O}}\right)$}

The $\mathrm{C}_{\mathrm{H} 2 \mathrm{O}}$ concentration verified in the water samples are presented in the figure below (Figure 7). It is possible to notice that the concentrations varied from 0 to $0.25 \mathrm{~g} \mathrm{~L}^{-1}$, with the mouth region (Três Marias) presenting a value $9 \%$ higher than the other regions, which did not differ statistically $(p<0.0001)$. 


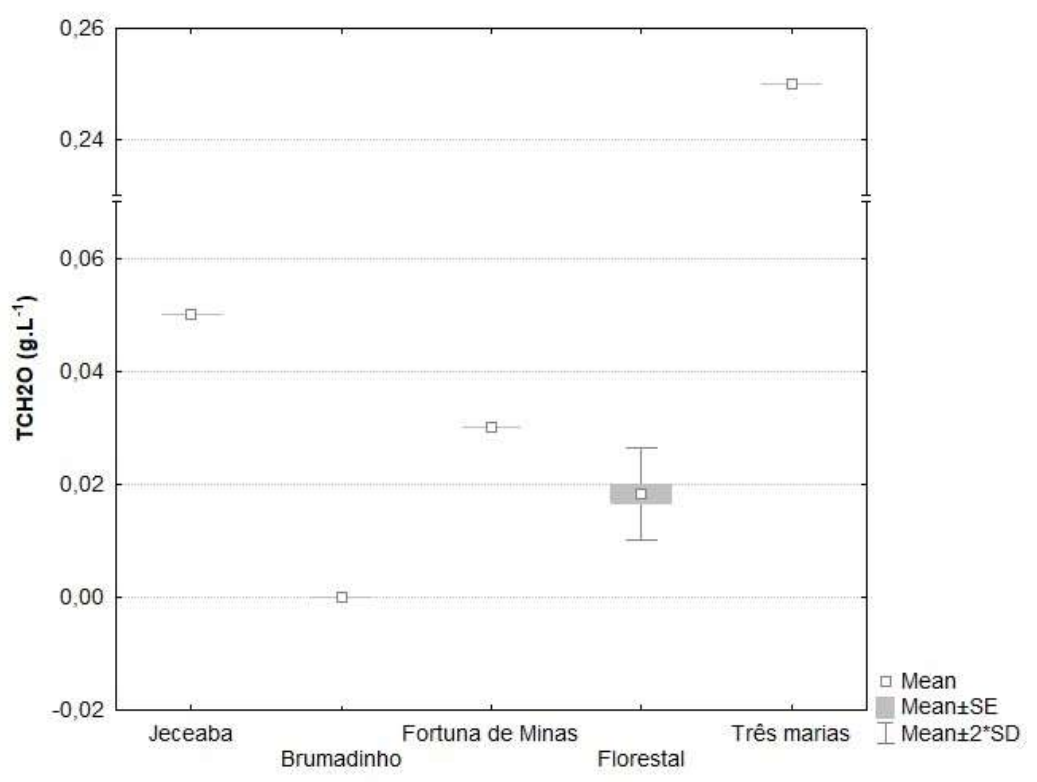

Figure 7: C levels in the waters of the Paraopeba River basin (MG).

Regarding the $\mathrm{C}_{\mathrm{H} 2 \mathrm{O}}$ concentration found in the water samples, the levels were very low in relation to other studies. Alberts et al. (1990) found $\mathrm{C}_{\mathrm{H} 2 \mathrm{O}}$ values for rivers in the southeastern United States that ranged from 0.31 to $2.29 \mathrm{~g} \mathrm{~L}^{-1}$. Wen (1992) found similar values in the study of the Changjiang River, in China, which ranged between 0.34 and $2.13 \mathrm{~g} \mathrm{~L}^{-1}$. Wetzel (1992), in his study on Lake Lawrence, in Michigan, USA, found minimum and maximum $\mathrm{C}_{\mathrm{H} 2 \mathrm{O}}$ values around 1.73 and $2.73 \mathrm{~g} \mathrm{~L}^{-1}$, respectively. All the previously cited values proved to be higher than those verified in the present study.

An explanation for the low $\mathrm{C}_{\mathrm{H} 2 \mathrm{O}}$ values found in the Paraopeba River basin is the "sediment input" with low organic matter content. According to Robarts et al. (1988), the relative importance of indigenous and allochthonous $\mathrm{C}_{\mathrm{H} 2 \mathrm{O}}$ inputs to rivers will depend on several factors, such as the use of the area, the activities developed in its surroundings, the extent of the basin, and the trophic level at which an aquatic system is found. It is possible to infer that the ecosystems studied in this work sequester $\mathrm{C}$ in sediments in a more intense manner, as they have more weathered mineralogy, and there is a nascent/empty flow.

In the Brumadinho region, the $\mathrm{C}_{\mathrm{H} 2 \mathrm{O}}$ levels were not identified. It may have happened because such region is under the constant influence of sand extraction and mining, a fact that moves water in the sample site propitiating the migration of organic material to other points, evidenced by the enrichment in the direction from the head to the mouth of the river. The positive correlation found between the $\mathrm{C}$ content found in the water $\left(\mathrm{C}_{\mathrm{H} 2 \mathrm{O}}\right)$ and the aluminum content $(r=0.74)$ (Figure 3B) can be explained by the complexation of $\mathrm{Al}^{3+}$ by the $\mathrm{OM}$, which was incorporated into the water body by processes of percolation (OLIVEIRA, 2018).

This fact differs from the one found by Cóser (1990). When analyzing the effect of different coverings on the chemical and physical characteristics of an Alicos Red-Yellow Oxisol, he found a lower correlation value $\left(r=0.24^{*}\right)$. It is worth mentioning that the high correlation between the levels of $C_{\text {sed }}$ and $C_{H 2 O}$ with aluminum, a metallic ion, allows us to infer that heavy metal pollution could be present in these sediments, and could lead a potential environmental impact. 


\section{CONCLUSIONS}

The levels of $\mathrm{C}, \mathrm{N}$, and $\mathrm{C} / \mathrm{N}$ ratio proved to be sensitive indicators to disturbances that occurred in the aquatic ecosystem, due to changes in land use around the basin. The highest $\mathrm{C}$ levels were found in the Fortuna de Minas region, which had a C content 22.5\% higher than the other regions evaluated. The lowest levels of $\mathrm{C}$ were found in the Florestal region, which had the highest value for $\mathrm{N}, 28 \%$ higher compared to the others. The lowest levels of $\mathrm{N}$ were observed in the Jeceaba region. For the $\mathrm{C} / \mathrm{N}$ ratio, the region that showed the highest value was Brumadinho, which presented a $47 \%$ higher $\mathrm{C} / \mathrm{N}$ ratio compared to the other regions, and in contrast, the lowest ratio was found in the Florestal region. Regarding the $\mathrm{C}$ content in the waters, we found that the Três Marias region had a C content $9 \%$ higher than the other areas under study. From the correlation analysis, it was possible to verify that the $\mathrm{C}_{\mathrm{H} 2 \mathrm{O}}$ and $\mathrm{C}_{\text {sed }}$ correlated with the $\mathrm{Al}^{3+}$ content, showing disturbance in the system by heavy metals.

ACKNOWLEDGMENTS: To the soil and plant production laboratory of the Federal University of Viçosa for the structural support in the development of the research. The Fundação de Amparo à Pesquisa do Estado de Minas Gerais for financial support.

\section{REFERENCES}

ALBERTS, J. J.; ERTEL, J. R.. Characterization of organic matter in rivers of the Southeastern United States. Verh. Internat. Verein. Limnol., v.24, p.260-262, 1990.

ALMEIDA, M. G.; REZENDE, C. E.; SOUZA, C. M. M.. Variação temporal, transporte e partição de hg e carbono orgânico nas frações particulada e dissolvida da coluna d'água da Bacia inferior do Rio Paraíba do Sul, RJ, BRASIL. Geochimica Brasiliensis, v.21, n.1, p.111-128, 2007.

ALVAREZ, V. V. H.; NOVAIS, R. F.; BARROS, N. F.; CANTARUTTI, R. B.; LOPES, A. S.. Interpretação dos resultados das análises de solos. In: RIBEIRO, A. C.; GUIMARÃES, P. T. G.; VENEGAS, V. H. A.. Recomendações para uso de corretivos e fertilizantes em Minas Gerais: 5a Aproximação. Viçosa, Comissão de Fertilidade do Solo do Estado de Minas Gerais. 1999. p.25-32.

AYRES NETO, A. A.; MOTA, B. B.; BELEM, A. L.; ALBUQUERQUE, A. L.; CAPILLA, R.. Seismic peak amplitude as a predictor of TOC content in shallow marine sediments. Geo-Marine Letters, v.36, n.5, p.395-403, 2016.

BALDOTTO, M. A.; VIEIRA, E. M.; SOUZA, D. D. O.; BALDOTTO, L. E. B.. Estoque e frações de carbono orgânico e fertilidade de solo sob floresta, agricultura e pecuária. Revista Ceres, v.62, n.3, p.301-309, 2015.

BADER, R. G.. Carbon and nitrogen relations in surface and subsurface marine sediments. Geochimica et Cosmochimica Acta, v.7, n.5-6, p.205-211, 1955.

CAMPELO, F. R.; SOUZA, J. C. R.; DRAY, W. T.. Impactos do uso e ocupação do solo e do curso d' água no lago Macurany. Brazilian Journal of Development, v.6, n.10, p.81618-81631, 2020.

CANUEL, E. A.. Relations between river flow, primary production and fatty acidcomposition of particulate organic matter in San Francisco and Chesapeake Bays: a multivariate approach. Organic Geochemistry, v.32, p.563-583, 2001.

CEBRON, A.; GARNIER, J.. Nitrobacter and Nitrospira genera as representatives of nitrite-oxidizing bacteria: detection, quantification and growth along the lower Seine River (France). Water Research, v.39, n.20, p.4979-4992, 2005.

CÓNSUL, J. D.. Decomposição catalítica de óxidos de nitrogênio. Química Nova, v.27, n.3, p.432-440, 2004.

CÓSER, A. C.. Efeito de diferentes coberturas vegetais sobre as características físicas e químicas de um Latossolo Vermelho-Amarelo álico. Revista Ceres, v.37, n.210, p.167176, 1990.

CUNHA, A. D. C. D.. Modelo matemático de avaliação do processo de autodepuração de matéria orgânica em reservatórios: uma ferramenta de gestão. 2020.

CRUZ, C. D.. Análise multivariada e simulação. Viçosa: UFV, 2006.

DICK, D. P.; ROCCHI, E. A.; LEITE, A. J. B.; CABRAL, N. C. B.. Ácidos húmicos de materiais carbonosos: extração e composição. In: CONGRESSO BRASILEIRO DE CARVÃO MINERAL, 4. Anais. Gramado, 2013.

EMBRAPA. Manual de métodos de análise de solo. Rio de Janeiro: Embrapa Solos-Documentos, 1997.

EMBRAPA. Sistema brasileiro de classificação de solos. Rio de Janeiro: Centro Nacional de Pesquisa de Solos, 2013.

FERREIRA, S. C. G.; LIMA, A. M. M. D.; CORRÊA, J. A. M.. Zoneamento da bacia hidrográfica do rio Moju (Pará): usos da água e sua relação com as formas de uso e cobertura do solo. Revista Ambiente \& Água, v.12, n.4, p.680-693, 2017. 
GUTIERREZ, C. B. B.; RIBEIRO, H. M. C.; MORALES, G. P.; GUTIERREZ, D. M. G.; SANTOS, L. D.; PAULA, M. D.. Análise espaço temporal do uso e cobertura do solo no interior da APA Belém e correlação com os parâmetros de água dos seus mananciais. Rev. Bras. Geogra. Física, v.10, n.1, p.521534, 2017.

KALAIVANAN, R.; JAYAPRAKASH, M.; NETHAJI, S.; ARYA, V.; GIRIDHARAN, L.. Geochemistry of Core sediments from tropical mangrove region of Tamil Nadu: implications on trace metals. J. Earth Sci Clim Change, v.8, n.385, p.2, 2017.

LIMA, M. M. R. B. F.. Diagnostico e evolução de algumas espécies químicas e matéria orgânica em perfil sedimentar holecênico no estuário do Rio Manguaba, Estado de Alagoas. Dissertação (Mestrado) - Universidade Federal de Pernambuco, Recife, 2007.

MAYERS, P. A.; LALLIER-VERGES, E. L.. Lacustrine sedimentary organic matter records of late Quaternary paleoclimates. Journal of Paleolimnology, v.21, n.3, p.345372, 1999.

MEIXNER, F. X.; WERNER, E.. Effects of landscape pattern and topography on emissions and transport. In: Integrating hydrology, ecosystem, dynamics, and biogeochemistry in complex landscapes. New York: Wiley, 1999. p.147-175.

MOROZOVA, G. S.; SMITH, N. D.. Organic matter deposition in the Saskatchewan River floodplain (Cumberland Marshes, Canadá): effects of progradational avulsions. Sedimentary Geology, v.157, p.15-29, 2003.

OLIVEIRA, A. S. D.. A matéria orgânica na redução do efeito tóxico do alumínio. Thesis (Bachelor's) - Universidade Tecnológica Federal do Paraná, Curitiba, 2018.

OLSON, J. S.. Atmospheric Carbon Dioxide and the Global Carbon Cycle. Washington: U.S. Department of Energy, 1985.

PANHOTA, R. S.; BIANCHINI JUNIOR, I.. Potential cycling of organic matter in an eutrophic reservoir (Barra Bonita, SP Brazil). Acta Limnologica Brasiliensia, v.15, n.2, p.1-11, 2003.

PEREIRA, S. B.; LIMA, W. N.; ROBRINI, M. E.. Caracterização química e aspectos geoquímicos relevantes da matéria orgânica de sedimentos em suspensão na foz do rio Amazonas. Ciências Naturais, v.1, n.1, p.167-179, 2006.
ROBARTS, R. D.; ASHTON, P. J.. Dissolved organic carbon and microbial activity in a hypertrophic African reservoir. Arch. Hydrobiologia, v.113, n.4, p.519-539, 1988.

RODRIGUES FILHO, J. L.; DIAS, R. M.. Brazil in the mud again lessons not learned from Mariana dam collapse. Biodivers. Conserv., p.10-13, 2019.

SILVA, A. R. D.. Avaliação do processo de eutrofização das águas superficiais, do cenário nacional ao local: estudo de caso nas bacias hidrográficas costeiras dos rios Ratones, Itacorubi e Tavares (Ilha de Santa Catarina, Brasil). 2019.

STEEL, R. G. D.; TORRIE, J. H.. Principles and procedures of statistics. New York: McGraw, 1960.

SWANK, W. T.; DA JUNIOR, C.. Forest hydrology and ecology at Coweeta. Springer Science \& Business Media, 2012.

TUMIATI, S.; TIRABOSCHI, C.; MIOZZI, F.; VITALEBROVARONE, A.; MANNING, C. E.; SVERJENSKY, D. A.; POLI, S.. Dissolution susceptibility of glass-like carbon versus crystalline graphite in high-pressure aqueous fluids and implications for the behavior of organic matter in subduction zones. Geochimica et Cosmochimica Acta, 273, 383-402, 2020.

THOMPSON, F.; OLIVEIRA, B. C.; CORDEIRO, M. C.; MASI, B. P.; RANGEL, T. P.; PAZ, P.; REZENDE, C. E.. Severe impacts of the Brumadinho dam failure (Minas Gerais, Brazil) on the water quality of the Paraopeba River. Science of The Total Environment, v.705, p.135914, 2020.

VITOUSEK, P. M.; GOSZ, J. R.; GRIER, C. C.; MELILLO, J. M. REINERS, W. A.; TODD, R. L.. Nitrate losses from disturbed ecosystems. Science, v.204, n.4392, p.469-474, 1979.

WEN, Y. H.. Seston in a seasonally flooded lake of the central changjiang River (China). Hydrobiologia, v.242, p.95-104, 1992.

WETZEL, R. G.. Gradient-dominated ecosystems-sources and regulatory functions of dissolved organic-matter in freshwater ecosystems. Hydrobiologia, v.229, p.181-198, 1992.

WETZEL, R. G.; HATCHER, P. G.; BIANCHI, T.. Natural photolysis by ultraviolet irradiance of recalcitrant dissolved organic metter to simple substrates for rapid bacterial metabolism. Limnology and Oceanography, v.40, p.13691380, 1995.

A CBPC - Companhia Brasileira de Produção Científica (CNPJ: 11.221.422/0001-03) detém os direitos materiais desta publicação. Os direitos referem-se à publicação do trabalho em qualquer parte do mundo, incluindo os direitos às renovações, expansões e disseminações da contribuição, bem como outros direitos subsidiários. Todos os trabalhos publicados eletronicamente poderão posteriormente ser publicados em coletâneas impressas sob coordenação da Sustenere Publishing, da Companhia Brasileira de Produção Científica e seus parceiros autorizados. Os (as) autores (as) preservam os direitos autorais, mas não têm permissão para a publicação da contribuição em outro meio, impresso ou digital, em português ou em tradução. 